UDC 336.146

JEL Classification: C100, C130, C240, D140, 1280

http://doi.org/10.21272/mmi.2018.4-26

Aldona Migala-Warchol, Ph.D., Rzeszow University of Technology, Poland

Monika Pasternak-Malicka,

Ph.D., Rzeszow University of Technology, Poland

\title{
LIVING STANDARDS OF EU COUNTRIES' RESIDENTS: IMPACT OF EDUCATION AND INNOVATION
}

Abstract. The aim of the publication is an attempt to assess the impact of the level of education and innovation on a synthetic measure of living standards of European Union countries residents based on the estimation of the model in which the synthetic measure will be a dependent variable. The implementation of the objective required the use of descriptive-statistical methods, in particular, linear regression method. The Pearson's linear correlation coefficient was also used to study the relationship between quantitative variables - the synthetic measure and particular analysed determinant. The publication describes the essence of education and the level of innovation in the European Union countries and also reviews the theoretical concept of quality and standard of living in an objective approach. On the basis of Eurostat data from years 2006-2016, an attempt was made to assess the impact of higher education on the standard of living of the inhabitants of the European Community. The standard of the living measure will be calculated on the basis of five determinants: Economy and Finance, Science and Technology, Health, Education and Living Conditions. One of the authors of this paper enriched the dimensions of HDI indicator and proposed the modified index of the level of living. On the basis of the values of synthetic measures for each determinant of the standard of living, the final synthetic measure will be calculated as an arithmetic mean. The necessity of finding a new measurement of the standard of living in societies is emphasized by international organizations and especially scientists. That is why the author decided to modify the standard measure. Nowadays important factors are also science and technology and the standard of human living. The conducted research allowed to determine the relationship between the synthetic measure and important determinants characterizing the level of life. Finally estimated parameters of the linear regression models allowed to get the positive effects of education and innovation on the lives of individuals in the European Community.

Keywords: quality of life, determinants of the standard of living, diversity of living standards, education, personal finance, synthetic measure.

Introduction. The level of education is one of the basic determinants of the quality of human capital, therefore it affects the economic development on a macro scale. On a micro scale, it influences the development of the individual by shaping its consumer aspirations, and even more broadly, the hierarchy of values. On the other hand, due to the financial status obtained thanks to the education achieved, it allows for satisfying ever more sophisticated needs. The level of knowledge of the individual determines people's professional abilities, as well as determines the social position, builds self-esteem, shapes the lifestyle.

The aim of the publication is an attempt to assess the impact of the level of education on the synthetic indicator of living standards of EU countries based on the estimation of the model in which the synthetic measure will be a dependent variable. The implementation of the objective required the use of descriptivestatistical methods, in particular, the linear regression method. The Pearson's linear correlation coefficient was also used to study the relationship between quantitative variables.

The research results were obtained thanks to data gained from Eurostat. The article presents a synthetic measure of living standards, which calculation allowed to assess the variation of the analysed variable depending on individual partial variables, and then to assess to what extent having of higher education affects the standard of living of EU citizens. The implementation of the objective required the

Cite as: Migala-Warchol, A., \& Pasternak-Malicka, M. (2018). Living Standards of EU Countries' Residents: Impact of Education and Innovation. Marketing and Management of Innovations, 4, 307-315. http://doi.org/10.21272/mmi.2018.4-26 

and Innovation

use of descriptive-statistical methods, in particular, the linear regression method. The Pearson's linear correlation coefficient was also used to study the relationship between quantitative variables.

The essence and the level of education in the EU. Education as a social process is associated with a man from the beginning of its existence. The definition of this process derives from the Latin word education which means education, Etymology [6].

Education is a process that facilitates learning or acquiring knowledge, skills, values, beliefs and habits. Educational methods include a discussion, teaching, training and targeted research Dewey J. [4]. Education can take place in formal or informal settings May S. and other [17] and based on various experiences and methods Pashler $\mathrm{H}$. and others [19] which have a significant impact on the way of thinking, feeling or acting.

There is no unanimity regarding the formulation of education goals. Some authors emphasize its value for an individual, the potential to positively influence personal development, shaping the cultural identity or creating a career. Other authors emphasize the contribution of education to social goals. According to them, it is necessary to maintain civic order, a sense of national unity, maintaining economic growth or reducing poverty. Education is inseparable from culture, it is the main instrument for the development of civilization Winch Ch., and others [30].

The education system can fulfil three basic functions to a greater or lesser extent Werfhors $\mathrm{H}$. [29]:

- shaping the social structure according to the level of education and the level of income and the prestige associated with it;

- increasing the modernization potential of society;

- adapting the education structure to the demand and structure of the labour market.

Currently, most economists believe that knowledge is a new generation factor. Therefore, the basic task of the education system is a transfer of knowledge and practical skills. A well-trained workforce is indispensable for achieving a constant growth and economic development Hanushek E. A. [12]. In a postindustrial society, often referred to as a "knowledge-based society", the role of the school is changing. Its basic task is not to transfer encyclopaedic knowledge, but to learn how to learn. Education and the labour market are two social spheres that interact with each other. The development of the economy depends to a large extent on the quality of personnel that provides the education system.

Education affects the quality of human resources being one of the most important elements of the economy. Human resources are of great importance for the effective functioning of the organization Terpstra D. and others [25]. The importance of human capital management results for many reasons. One of the main reasons is the fact that these are people who decide how to use all the resources of an enterprise. Whether the business entity succeeds depends primarily on the skills and attitudes of the people who work in its Davenport Th. O. [3]. Without them, even the best and most competitive material, monetary or information resources can be wasted and contribute to the organization's failure Penrose E. T. [19].

In the European Union, the average percentage of people with higher education in 2016 was $39.1 \%$. It was almost half a percentage point more than in 2015 and 10 points above the 2006 level. In eighteen Member States, the Europe 2020 target of at least $40 \%$ was achieved. Fourteen countries of the community also achieved national targets in terms of the proportion of people with higher education. These are Denmark, Germany, Estonia, Greece, Italy, Cyprus, Latvia, Lithuania, Hungary, the Netherlands, Austria, Slovenia, Finland and Sweden Europen Comision [7].

Despite a widespread progress in achieving this goal, the proportion of people with higher education still varies greatly depending on the sex and place of birth. In the majority of Member States, young women are much more likely to obtain higher education: the average percentage of women with higher education is higher by almost 10 percentage points than in the case of men. In addition, natives usually have higher rates of higher education than those born abroad Ballas D. D. and others [2]. 

and Innovation

Education and the level and quality of life. Recent years have seen a growing interest in issues such as the level or quality of life of the population, although there are no definite definitions in the literature on the subject. Quality of life is the degree of satisfaction of material and non-material needs of individuals, families and communities. The concept used in a social policy seems to refer to the individuals and their subjective evaluation. Research on the quality of life concerns: the needs met by the consumption of goods and services (standard of living, life-rate), content of relations and social ties (e.g. the level of cooperation of social integration, intensification of individual and collective conflicts); the quality of life is determined by objective ratios (quantitative and qualitative, factual and valuable) and subjective (e.g. satisfaction with living conditions).

On the other hand, the standard of living is a concept conditioned by a number of different features and refers to macro and microeconomic ratios as well as statistical data. The paper includes the following determinants of the standard of living: Economy and Finance, Science and Technology, Health, Education, and Living Conditions. The above determinants were distinguished on the basis of the analysed literature as well as their own reflections.

The concepts related to the quality of life can be divided into two groups. The first one will include economic prosperity, living conditions, the standard of living, the life rate and the living level [31]. The other one includes quality of life, the way of life and lifestyle. The first group consists of the so-called quantitative terms, while the second group consists of qualitative terms. Depending on whether one deals with a concept considered quantitatively or qualitatively, different research methods are used. Quantitative methods are used to study quantitative terms, while survey methods, surveys, etc. are used to study qualitative terms.

In the literature on the subject, it is assumed that Allardtb E. [1] initiated the study of quality of life, defined the standard of living as a degree of satisfaction of material and cultural needs associated with widely understood possession (to have), and the quality of life, according to a Finnish scientist, are emotional states that flow from interpersonal relations (to love) and a sense of being related to the needs of self-fulfilment (to be).

Taking advantage of the concept of quality of life, which was created by T. Fahey, B. Nolan and C. Whelan [8], it should be stated that the feelings of individual people are of key importance in the study of the quality of life. The economic and social situation of the public is important, but only for purposes of proper interpretation of the obtained results. In addition, the idea of the quality of life is a multi-faceted concept. A consideration of several areas of human functioning allows deepening the narrow aspect related only to the income or material conditions of an individual Diener E. [5]; Griffin J. [10]. The multifaceted quality of life not only requires the description of several areas of life, but the interaction between these areas and the impact of this influence on the quality of life is particularly important Haller M. and others [11]; Frei B. S. [9].

The definition of the quality of life formulated by the UN expert committee [United Nations [26] in 1954 defines the concept of living standards as the overall conditions of human life and the degree of their material and cultural fulfilment of needs through a stream of goods and services paid for, and also from social funds. The definition of the standard of living presented by the UN expert committee has been the basis of many other approaches to this phenomenon.

When comparing the concepts of the quality and the standard of living, it can be concluded that the standard of living should be determined on the basis of a set of objective measures, while the quality of life should be determined on the basis of a set of subjective indicators. Objective measures record the existing real state of affairs (the level and structure of income or expenditure), and subjective indicators inform about how this state of affairs is perceived and assessed by individual persons or social groups.

A significant part of research on the level and quality of life focuses on positive economic and social outcomes, whereby learning can concern individuals as well as societies. Better educated people tend to 

and Innovation

have better health, are characterized by lower unemployment, wider social contacts and greater involvement in civic and political life. Research is also being conducted to examine the relationship with investments in education and the quality of life in a given country.

Investments in education and research are expressed in terms of expenditure on education and research, financial assistance for pupils and students, and public subsidies for the private sector. Three well-known composite indices are taken into account in the assessment of the quality of life: the social development index, the Life Quality Index of the Economist Intelligence Unit and the index of life satisfaction. The analyzes are most often made on the basis of data on the 27 Member States of the European Union which come from the Eurostat database and from the websites of specialized institutions. The study most often shows a positive relationship between investments in education and quality of life. Annual expenditure on public and private educational institutions per student is determined, as well as gross national expenditure on research and development as indicators of investments in education that best predict the quality of life in a given country lonescu $\mathrm{D}$. D. and others [14].

It seems that there is a consensus that education brings a number of benefits (cash and non-monetary ones), which both the person investing in education and the society in which better-educated people use Stiglitz J. E. and others [24]. Schuller T. [23] identifies earnings, income, assets and productivity as potential monetary learning outcomes for individuals while learning outcomes at the public level relate to tax revenue, social transfer costs, and health care costs. The same author also suggests positive nonmonetary learning outcomes of people in the form of improved health and life satisfaction. At the community and public level, non-monetary learning outcomes related to social cohesion, trust, wellfunctioning democracy and political stability.

Among the social effects of learning Pfeifer A. [21], he lists the following relationships: a well-educated person can achieve social and occupational progress on their own; in addition, income levels and higher living standards are positively correlated with more and better education. Education helps a person and helps people become more active, gain control over their own lives and broaden the range of available options UNESCO, 1997, [in:] Khan H. and others [15].

In addition to affecting the earnings and productivity of people, education helps them achieve different results that are relevant to $\mathrm{QOL}$ calculations. Research indicates that people who attended the school for longer or obtained higher education more often report better subjective well-being Oreopoulos P. [18]; Helliwell J. F. [13], enjoy better health and participate more actively in society.

Better educated people record lower mortality rates Mackenbach J. P. [16], have less serious health problems (such as diabetes and high blood pressure) and rarely suffer from minor illnesses (such as colds, headaches and pains) Stone A.A. and others [25], and also have better access to healthcare van Doorslaer E. and others [28].

The methodology of Research. The construction of the synthetic measure of development requires the division of diagnostic variables set to stimulants and destimulants. Variables included in the set of stimulants have been marked with the sign $(+)$, while the $(-)$ granted destimulants. The transformation of destimulants to stimulants was made according to the following formula:

$$
x_{i j}^{\{S\}}=\max _{i} x_{i j}^{\{D\}}-x_{i j}^{\{D\}}
$$

where $x_{i j}$ - value of the j-th variable for the i-th country; $S$ - symbol indicates stimulant, while the symbol; D - destimulant.

Then, after the transformation of destimulants to stimulants, the normalization of variables was used according to the following formula: 


$$
u_{i j}=\frac{x_{i j}}{\max _{i}\left\{x_{i j}\right\}}(i=1, \ldots, n ; j=1, \ldots, m)
$$

where $u_{i j}$ - normalized value of the j-th variable for the i-th country; $n$ - number of countries; $m-$ number of variables.

Synthetic measure of the socio-economic development was calculated by the following formula:

$$
u_{i}=\frac{1}{r} \sum_{q=1}^{r} u_{i q},(i=1, \ldots, n ; q=1, \ldots, r)
$$

where $u_{i q}$ - synthetic variable value for the i-th country calculated on the basis of the variables belonging to the q-th determinant; $r$ - number of determinants.

In contrast, measures of socio-economic development according to separate determinants was calculated using the following formula:

$$
u_{i q}=\frac{1}{m} \sum_{j=1}^{m} u_{i j},(i=1, \ldots, n ; j=1, \ldots, m)
$$

A detailed list of indicators used for the construction of indicators for individual determinants of socioeconomic development has been given below. Indicators have been selected based on the availability of Eurostat data for the years 2006-2016. The necessity of finding a new measurement of the quality of life of societies is emphasized by international organizations and especially scientists. That is why the author decided to modify the standard measure. Nowadays important factors are also science and technology and the standard of human living. That is why in this paper, the following determinants of socio-economic development will be used:

1. Economy and Finance: unemployment rate (-); GDP per capita $1(+)$; indicator of real expenditure per 1 inhabitant (+); the number of poor people per 1000 inhabitants $(-)$.

2. Science and Technology: gross domestic expenditure on R\&D (\% of total expenses) (+); human resources in science and technology (\% of the active population) $(+)$; the number of patent applications submitted to the European patent office per million inhabitants $(+)$; the number of researchers per 1000 inhabitants $(+)$.

3. Health: self-perceived long-standing limitations in usual activities due to health problem (-); selfreported unmet needs for medical care due to being too expensive $(-)$; expected life expectancy $(+)$; number of doctors per 1000 inhabitants (+); number of beds in hospitals per 100000 inhabitants $(+)$.

4. Education: participation rate in education and training (persons aged 25 to 64 years old) $(+)$; the percentage of people with at most lower secondary education and with no further education at the age of 18-24 years old (-); the percentage of people gaining or with higher education aged 15 to $64(+)$; the percentage of people with secondary education between the age of 15 to $64(+)$.

5. Living Conditions: the percentage of people who are unable to meet unexpected financial expenses (-); the percentage of people who are not able/unable to make 'ends meet' (-); the rate of people at risk of poverty (-); share of people living in under-occupied dwellings $(+)$.

Positive impact of education on the standard of living of EU citizens in empirical research. Figures 1-2 show linear regression models, in which Synthetic measure is the dependent variable, and the independent variable on the first chart is Science and Technology and on the second one is Education. 
A. Migala-Warchol, M. Pasternak-Malicka. Living Standards of EU Countries' Residents: Impact of Education and Innovation

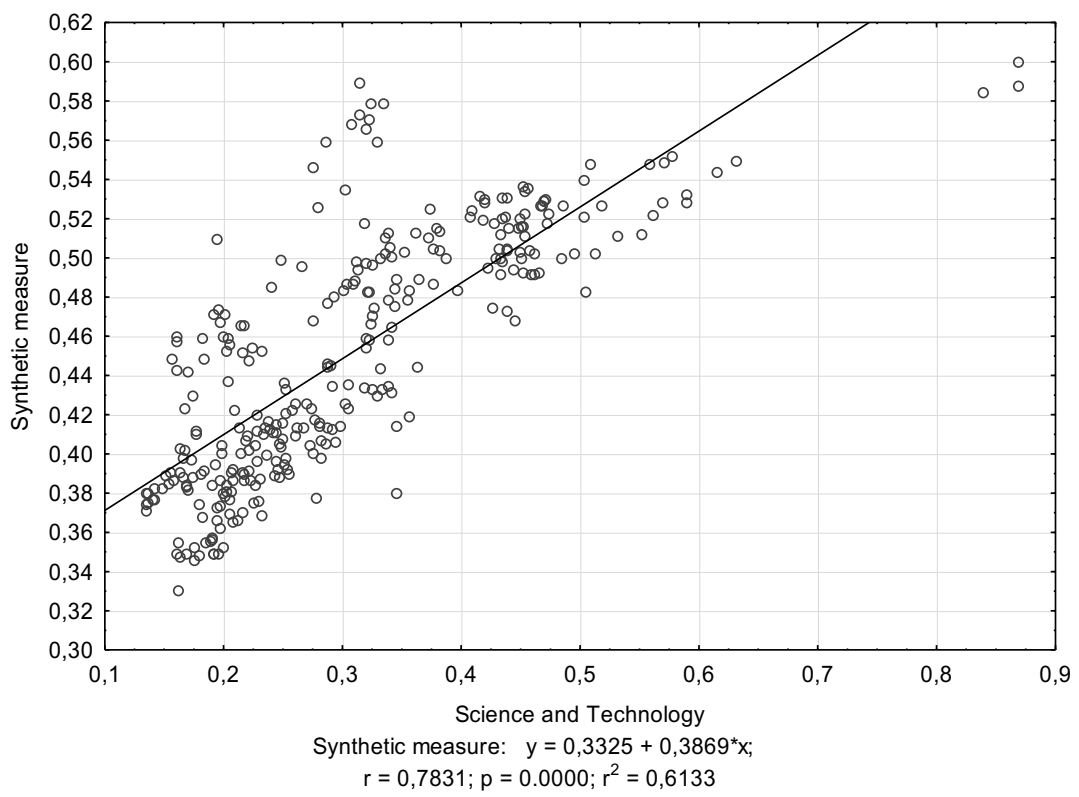

Figure 1 - Regression function parameters - synthetic measure in terms of Science and Technology

Sources: author's calculations

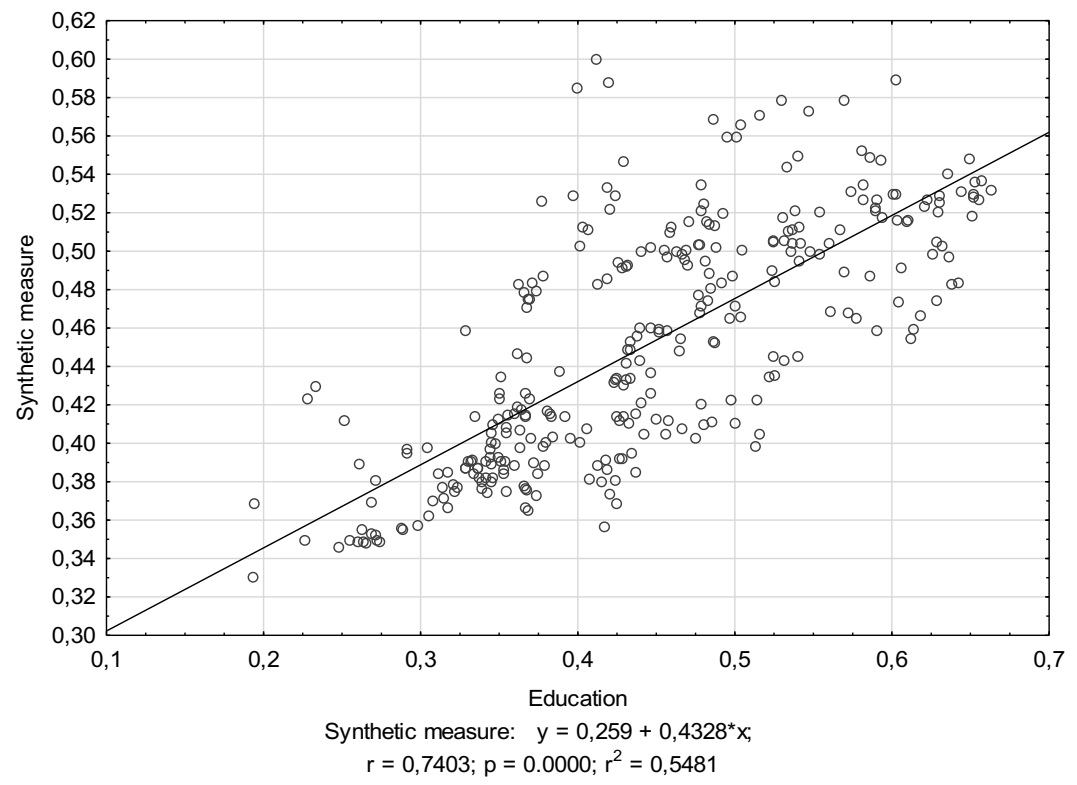

Figure 2 - Regression function parameters - synthetic measure in terms of Education

Sources: author's calculations 

and Innovation

Table 1 - Correlation coefficients between determinants and the synthetic measure of socioeconomic development in the European Union countries

\begin{tabular}{|c|c|c|c|c|c|c|c|c|}
\hline & \multicolumn{6}{|c|}{ Correlations (correlation coefficients are relevant for $p<, 050)$} \\
\cline { 2 - 9 } Determinants & $\begin{array}{c}\text { Avera } \\
\text { ge }\end{array}$ & $\mathbf{s}$ & $\begin{array}{c}\text { Economy } \\
\text { and } \\
\text { Finance }\end{array}$ & $\begin{array}{c}\text { Science and } \\
\text { Technology }\end{array}$ & Health & $\begin{array}{c}\text { Educati } \\
\text { on }\end{array}$ & $\begin{array}{c}\text { Living } \\
\text { Condition }\end{array}$ & $\begin{array}{c}\text { Synthetic } \\
\text { measure }\end{array}$ \\
\hline $\begin{array}{c}\text { Economy } \\
\text { and Finance }\end{array}$ & 0,43 & 0,13 & 1,00 & $0,49^{*}$ & 0,05 & $0,44^{*}$ & 0,03 & $0,80^{*}$ \\
\hline $\begin{array}{c}\text { Science and } \\
\text { Technology }\end{array}$ & 0,31 & 0,13 & $0,49^{*}$ & 1,00 & 0,08 & $0,55^{*}$ & $-0,12^{*}$ & $0,78^{*}$ \\
\hline Health & 0,83 & 0,07 & 0,05 & 0,08 & 1,00 & $-0,24^{*}$ & $-0,48^{*}$ & 0,05 \\
\hline Education & 0,44 & 0,11 & $0,44^{*}$ & $0,55^{*}$ & $-0,24^{*}$ & 1,00 & $0,13^{*}$ & $0,74^{*}$ \\
\hline $\begin{array}{c}\text { Living } \\
\text { Condition }\end{array}$ & 0,24 & 0,10 & 0,03 & $-0,12^{*}$ & $-0,48^{*}$ & $0,13^{*}$ & 1,00 & $0,22^{*}$ \\
\hline $\begin{array}{c}\text { Synthetic } \\
\text { measure }\end{array}$ & 0,45 & 0,06 & $0,80^{*}$ & $0,78^{*}$ & 0,05 & $0,74^{*}$ & $0,22^{*}$ & 1,00 \\
\hline
\end{tabular}

\section{Source: author's calculations}

Figures 1-2 illustrate scatterplots prepared based on Eurostat data for the years 2006-2016. Analysing the results it should be stated that between the synthetic measure and Science and Technology variables a high positive dependence was obtained, which is indicated by the value of Pearson's linear correlation coefficient $(r=0,78)$. In the case of the study of the relationship between the synthetic measure and Science and Technology variables, Pearson's linear correlation coefficient was obtained at 0,74, which means high positive dependence. The obtained regression models allow for the interpretation of parameters as follows. If the Science and Technology increases by 1 , the synthetic measure of socioeconomic development increases by 0,39 . If the Education increases by 1 , then the synthetic measure of socio-economic development increases by 0,43 . Table 1 presents the values of Pearson's linear correlation coefficient between individual determinants and the synthetic measure. In the conducted research it was obtained that the determinants of 'Economy and Finance' $(r=0,80)$, 'Science and Technology' $(r=0,78)$ and 'Education' $(r=0,74)$ are the most correlated with the synthetic measure.

Conclusions. The education of citizens plays an essential role in the development of every country. Investments in human skills are the cheapest way to raise the level of competitiveness of the economy and accelerate the pace of economic development. At the same time, it can be a way to improve the quality and standard of living of individual citizens of the Community. Already in 1996 in the report of the International Commission for Education, entitled "Education: There is a hidden treasure" (Learning: the Treasure Within), it was emphasized that education should go far beyond the existing practice in European countries. At present, there is a tendency to increase the average level of education among EU citizens.

On the basis of Eurostat data from years 2006-2016, an attempt was made to assess the impact of higher education on the standard of living of the inhabitants of the European Community. In pursuing the goal of the publication, a research hypothesis has been adopted that higher education has a positive impact on the living standards of EU residents. The synthetic meter characterizing the standard of living was created on the basis of selected determinants: Economy and Finance; Science and Technology; Health; Education and Living Conditions. The conducted research allowed to obtain a positive strong dependence between the synthetic measure and significant determinants characterizing the level of life. Analysing the obtained results, it should be stated that between the synthetic measure and the variables Science and Technology, a high positive relationship was obtained, which is indicated by the value of 

and Innovation

Pearson's linear correlation coefficient $(r=0,78)$. In the case of the study of the relationship between the synthetic measure and the variables Education, the Pearson linear correlation coefficient was obtained at 0,74 , which means a high positive relation. The obtained regression models allow for the interpretation of parameters in the following way. If Science and Technology increase by 1 , the synthetic measure of socioeconomic development will increase by 0,39 . If Education increases by 1 , then the synthetic measure of socio-economic development will increase by 0,43 . The obtained results allow confirming the accepted research hypothesis that the level of education positively affects the standard of living of EU citizens.

The positive effects of education on the lives of individuals as well as on communities and society are numerous and diverse. Better educated people tend to have better health, better work, more social contacts and greater involvement in civic and political life. There is agreement that education brings a number of benefits (both monetary and non-monetary), which both the person investing in education and the community in which he or she lives benefits.

It seems that at an individual level investing time, energy and money in education contributes to the improvement of employment and income for the individual. At the social level, investment in education contributes to human capital as a resource that increases the well-being of future generations.

\section{References}

1. Allardt E., (1993). Having, Loving, Being: An Alternative to the Swedish Model of Welfare Research [w:] M. Nussbaum, A. Sen (red.), The Quality of Life, Oxford, Clarendon Press.

2. Ballas D., Lupton R., Kavroudakis D., Hennig B. (2012). Mind the gap. Education inequality across EU regions. European Union, NESSE, http://www.nesse.fr/nesse/activities/reports/activities/reports/mind-the-gap-1

3. Davenport Th.O. (1999). Human Capital What It Is and Why People Invest It, Jossey-Bass Publishers, San Francisco, s.186.

4. Dewey, J. (1944). Democracy and Education. The Free Press. pp. 1-4.

5. Diener E., Biswas-Diener R. (2002). Will Money Increase Subjective Well-Being?[w:] A.C. Michalos (red.), Social Indicators Research: An International and Interdisciplinary Journal for Quality-of-Life Measurement, Springer.

6. Etymology Dictionary, Etymonline.com. https://www.etymonline.com/word/educate

7. Europen Comision, (2018). Education and Training Monitor, The Monitor is the European Commission's flagship annual publication on education and training in the EU, http://ec.europa.eu/education/policy/strategic-framework/et-monitor_pl; European Semester: Thematic factsheet - Active labour market policies (2017). https://ec.europa.eu/info/strategy/european-semester/ thematic-factsheets/labour-markets-and-skills_en

8. Fahey T., Nolan B., Whelan C. (2003). Monitoring quality of life in Europe, European Foundation for the Improvement of Living and Working Conditions, Office for Official Publications of the European Communities, Luxembourg

9. Frei B.S., Stutzer A. (2002). Happiness and Economics, Princeton University Press.

10. Griffin J. (1986). Well-Being, Oxford University Press, Oxford.

11. Haller M., Hadler M. (2006). How Social Relations and Structures can Produce Happiness and Unhappiness: An International Comparative Analysis [w:] Michalos A.C. (red.), Social Indicators Research: An International and Interdisciplinary Journal for Quality-of-Life Measurement, Springer 2006.

12. Hanushek E. A. (2005). Economic outcomes and school quality. International Institute for Educational Planning.

13. Helliwell, J. F. (2008). Life Satisfaction and Quality of Development, working paper 14507, National Bureau of Economic Research, Cambridge, pp. 166.

14. Ionescu D. D., Cuza A. I., Ionescu A. M., Cuza A. I., Jaba E. (2013). The Investments in Education and Quality of Life, Journal of Knowledge Management, Economics and Information Technology, Special Issue

15. Khan, H., Williams, J. B. (2006). Poverty Alleviation through Access to Education: Can E-Learning Deliver?, Working Paper No. 002/2006, July, pp.2.

16. Mackenbach, J. P., Health Inequalities: Europe in Profile, UK Presidency of the EU, February 2006

17. May S.; Aikman, S. (2003). Indigenous Education:Addressing Current Issues and Developments. Comparative Education. 39 (2), pp. 139-45; 

and Innovation

18. Oreopoulos, P. (2007). Do dropouts drop out too soon? Wealth, health and happiness from compulsory schooling, Journal of Public Economics, vol. 91 (11-12), December.

19. Pashler H., McDonald M., Rohrer D., Bjork R., (2009). Learning Styles: Concepts and Evidence, Psychological Science in the Public Interest. 9 (3): pp. 105-19

20. Penrose E.T. (1997). The Theory of the Growth of the Firm [w:] Resources, Firm and Strategies. A Reader in the ResourceBased Perspective, N.J. Foss, Oxford University Press, Oxford, pp. 30-35.

21. Pfeifer A. (2007) Good Practices in Basic Education in Latin America, OECD Conference, Istanbul, Turkey

22. Rogoff B., Callanan M., Gutiérrez K. D., Erickson F., (2016). The Organization of Informal Learning, Review of Research in Education. 40, pp. 356-401.

23. Schuller, T. (2007), Understanding the social outcomes of learning, Second OECD World Forum on Statistics, Knowledge and Policy, Istanbul, Turkey, June 30, pp.8.

24. Stiglitz, J. E., Sen, A. K., Fitoussi, J.P. (2009). Report by the Commission on the Measurement of Economic Performance and Social Progress; www.stiglitz-sen-fitoussi.fr, pp.46.

25. Stone, A. A., Krueger, A. B., Steptoe, A., Harter, J. (2010). The Socio-Economic Gradient, in Daily Colds and Flu, Headaches, and Pain, JAMA Internal Medicine

26. Terpstra D., Rozell E. (1993). The Relationship of Staffing Practices to Organizational Leve/ Measures of Performance, "Personnel Psychology", spring, pp. 27-38.

27. United Nations (UN) (1954) International definition and measurement of standards and levels of living 1954.IV.5. UN,

28. Van Doorslaer, E., Masseria, C. (2004). OECD Health Equity Research Group Members, Income-related inequality in the use of medical care in 21 OECD countries, OECD Health Working Papers No. 14, OECD, Paris.

29. Werfhors H. van de, Dronkers J., Karsten S., (2016). Educational systems and four central function of education, Research programme funded by NWO Programming Council for Educational Research (PROO) 2011-2015, http://www.hermanvandewerfhorst.socsci.uva.nl/PROOProgrammeDescription.pdf

30. Winch Ch., Gingell J. (2008). Philosophy of Education: The Key Concepts (2nd edition). London: Routledge, pp. 10-11.

31. Włodarczyk K. (2015), Quality of urban life in Poland, Journal of International Studies, 8(2), 155-163. DOI: 10.14254/2071$8330.2015 / 8-2 / 13$

A. Мігала-Вархол, Ph.D., Ржешовський технологічний університет (Польща);

M. Пастернак-Маличка, Ph.D., Ржешовський технологічний університет (Польща).

Рівень життя населення країн ЄС: вплив освіти та інновацій

Стаття присвячена аналізу впливу рівня освіти та інновацій на синтетичний індикатор рівня життя населення країн Європейського Союзу на основі емпіричної моделі, в якій синтетичний індикатор виступає залежною змінною. У ході дослідження було використано методи описової статистики, зокрема метод лінійної регресії. 3 метою виявлення взаємозв'язку між кількісними змінними - синтетичний індикатор та детермінантами якості життя населення - авторами розраховано коефіцієнт лінійної кореляції Пірсона. У роботі автори досліджують тенденцій розвитку системи освіти та інновацій у країнах Європейського Союзу, а також виокремлюють основні аспекти теоретичної концепції якості та рівня життя населення. Автори наголошують про необхідність пошуку та розробки нового індексу оцінки рівня життя суспільств, що також підкреслюється міжнародними організаціями та науковою спільнотою. у статті було модифіковано індекс суспільного розвитку (Human Development Index) за рахунок включення додаткових параметрів. На основі даних Євростату за 2006-2016 pp. було оцінено вплив вищої освіти на рівень життя населення Європейського співтовариства. При цьому якість життя розраховується на основі п'яти детермінант: економіка та фінанси, наука і технологія, охорона здоров'я, освіта та умови життя. Окрім цього у роботі обірунтовано необхідність врахування рівня розвитку наука і техніки при оцінці рівня життя суспільства. Проведене дослідження дозволило визначити зв'язок між синтетичним індикатором та визначеними детермінантами, що характеризують рівень життя. Так, збільшення на один пункт рівня розвитку науки і техніки призведе до підвищення синтетичного показника соціально-економічного розвитку на 0,39. Підвищення рівня освіти на один пункт призведе до збільшенні синтетичного показника соціально-економічного розвитку на 0,43. Емпіричні результати лінійноі регресії підтвердили позитивний вплив освіти та інновацій на рівень якості життя суспільства в Європейському співтоваристві.

Ключові слова: якість життя, детермінанти, рівень життя, освіта, особисті фінанси, синтетичний індекс.

Manuscript received: 11.10 .2018

(C) The author(s) 2018. This article is published with open access at Sumy State University. 